\title{
Tręšimo siera poveikis vasarinių kviečių derlingumui ir kokybei
}

Rūta Staugaitiené,

Alvyra Šlepetienè,

Lina Žičkienè

Lietuvos agrarinių ir mišku

mokslu centras,

Instituto al. 1,

LT-58344 Akademija, Kédainiu r.

El.paštas: ruta@alteja.lt;

alvyra@lzi.lt
Lietuvos agrarinių ir miškų mokslų centro filiale, Agrocheminių tyrimų laboratorijos vegetacinių bandymų aikštelëje, 2010-2012 m. buvo atlikti du vegetaciniai bandymai. Bandymams ịrengti buvo atvežti du skirtingi dirvožemiai. Pirmasis - smèlingas lengvo priemolio, sekliai karbonatingas, giliau glèjiškas rudžemis (Epicalcari - Endohypogleyic Cambisol), atvežtas iš Radviliškio r., Skèmiu bandymų lauko. Antrasis - smèlingas priemolio tipingas paprastasis išplautžemis (Haplic Luvisol), atvežtas iš Varenos r., Perlojos bandymų lauko. Vegetaciniuose induose auginta vasarinių kviečių veislè 'Triso', tręšta tokiomis sieros normomis: netręšta (kontrolè), $S_{20}, S_{40}, S_{60}$. Vidutiniais tyrimų duomenimis, karbonatingame rudžemyje ir paprastajame išplautžemyje sieros trąšos turèjo esminès įtakos vasarinių kviečių grūdų derliaus padidèjimui, didžiausias derlius gautas tręšiant $\mathrm{S}_{60}$ trą̧̌ų norma, o didesnis sieros trąšų efektyvumas derliui nustatytas vasarinius kviečius auginant karbonatingame rudžemyje. Žalių baltymų kiekis esmingai didesnis karbonatingame rudžemyje gautas tręšiant $S_{20}$ trą̌̌ų norma, o paprastajame išplautžemyje $-S_{20}$ ir $S_{60}$. Vidutiniais duomenimis, abiejuose bandymuose sieros trąšos neturèjo esminès įtakos krakmolo kiekiui kviečių grūduose, tačiau turëjo tendenciją didinti sausojo glitimo kiekį.

Raktažodžiai: dirvožemis, siera, vasariniai kviečiai, baltymai, glitimas

\section{IVADAS}

Nors vasariniai kviečiai ir nèra labai reiklūs sierai, tačiau pastaraisiais metais Vakarų Europoje pastebimas jos trūkumas. Esant sieros trūkumui užauginamas mažesnis ir prastesnès kokybès vasarinių kviečių derlius (Wrigley, Du Cros, Fullington, Kasarda, 1984; Castle, Randall, 1987; Fullington, Miskelly, Wrigley, Kasandra, 1987). Sieros kiekio svyravimai dirvožemyje gali neigiamai veikti kviečių kokybę ir sunkinti kviečių malimo bei duonos kepimo procesus. Kai trūksta grūduose sieros ir iš jų gaminama duona, tešla būna prasčiau minkoma. Subalansuotas tręšimas siera užtikrintų gausų ir kokybišką derlių (Moss, Wrigley, MacRitchie, Randall, 1983; Zhao, Hawkesford, McGrath, 1999).

Lietuvoje dèl klimato sąlygų ir išsiplovimo procesų sieros balansas dirvožemyje yra neigiamas (Gužys, Aksomaitienè, 2005). Dirvožemis sieros junginius mažai sorbuoja, todèl sulfatų koncentra- cija nuolat kinta. Radviliškio r., Skèmiuose, atlikus ilgametị bandymą nustatyta, kad kasmet su superfosfatu išberus vidutiniškai apie $68,6 \mathrm{~kg} \mathrm{ha}^{-1}$ sieros (S), azoto ir kalio trąšu , iš ariamojo sluoksnio išsiplauna $162 \mathrm{~kg} \mathrm{ha}^{-1}$ sulfatų (Adomaitis, Mažvila, Vaišvila, Arbačiauskas, Antanaitis, Lubyte, Šumskis, 2010). Mokslininkai S. Mestelan ir S. Pazos (1998) nurodo, kad kritiškai mažas kiekis judriosios sieros dirvožemyje yra tuomet, kai jos nustatoma $4-7 \mathrm{mg} \mathrm{kg}^{-1}$. S. P. McGrant, F. J. Ahao, M. M. A. Blake-Kalff (2002) teigia, kad $10 \mathrm{mg} \mathrm{kg}^{-1}$ judriosios sieros yra kritinè riba norint užauginti kviečius.

Pasak P. J. Hockingo (1994), tik apie 33 \% sieros iš lapų ir stiebų pereina i kviečių grūdus, o azoto - net $75 \%$. Tai rodo, kaip svarbu viso augimo metu išlaikyti augalui sieros prieinamumą, kad pakankamai jos susikauptų grūduose, nes rinka itin reikli kviečių derliaus kiekiui ir aukštai jų kokybei.

Norvegų mokslininkai, atlikę bandymą (naudodami sieros trąšas pagrindiniam ir papildomam 
tręšimui), nustatė, kad optimalu sieros trąšomis tręšti įterpiant $10 \mathrm{~kg} \mathrm{ha}^{-1}(\mathrm{~S})$ sejjos metu ir $16 \mathrm{~kg} \mathrm{ha}^{-1}$ vamzdelejjimo pradžioje. Panašus derlius gautas ir tręšiant $30+8 \mathrm{~kg} \mathrm{ha}^{-1}$. Tik nedideli kokybiniai pakitimai nustatyti didinant $S$ normą $\left(30+16 \mathrm{~kg} \mathrm{ha}^{-1}\right)$ (Flaete, Hollung, Ruud, Sogn, Færgestad, Skarpeid, Magnus, Uhlen, 2005). Jie pastebèjo, kad sieros normas didinant nuo vidutinių iki didelių, derliaus kiekiai labai nekinta, tačiau kokybè - kinta. Ateityje duonos pramonei gali būti svarbu užauginti tam tikros kokybės kviečius.

Vokietijos mokslininkai, atlikę vegetacini bandymą penkių litrų talpos vegetaciniuose induose, dviejuose skirtinguose dirvožemiuose (tręšdami siera), nustate, kad dulkiško priemolio dirvožemyje augintų kviečių vegetacija buvo trumpesnè ir derliaus vidurkis gautas $52 \%$ mažesnis nei kviečių, augintų smèlingame priemolyje. Daugiau azoto ir sieros nustatyta kviečių grūduose, kurie užauginti dulkiško priemolio dirvožemyje, o skirtingi sieros kiekiai turèjo įtakos grūdų derliui. Dulkiško priemolio dirvožemyje netręšiant siera derlius gautas $38 \%$ mažesnis, o smèlingame priemolyje - $48 \%$ mažesnis, palyginti su variantu, kur tręšta didžiausia (160 mg (S) indui) norma (Wieser, Guster, Tucher, 2004).

Tyrimų tikslas - nustatyti sieros trąšu įtaką vasarinių kviečių derliui ir sẻklų kokybei skirtinguose dirvožemiuose: tipingame karbonatingame, giliau glejiškame rudžemyje (Vidurio Lietuva) ir paprastajame išplautžemyje (Pietryčių Lietuva).

\section{TYRIMŲ METODAI IR SĄLYGOS}

\section{Tyrimų ịrengimo vieta ir dirvožemis}

Du vegetaciniai bandymai su skirtingais dirvožemiais atlikti 2010-2012 m. Lietuvos agrarinių ir miškų mokslų centro (LAMMC), Agrocheminių tyrimų laboratorijos vegetacinių bandymų aikštelëje. Vegetaciniuose cilindriniuose induose, dviejuose skirtinguose dirvožemiuose, auginti vasariniai kviečiai. Pirmam bandymui atlikti pasirinktas smèlingas lengvo priemolio, sekliai karbonatingas, giliau glejiškas rudžemis (Epicalcari - Endohypogleyic Cambisol), atvežtas iš LAMMC filialo, Agrocheminių tyrimų laboratorijos, Skemių bandymo lauko. Ariamajame dirvožemio sluoksnyje vyrauja $54,7 \%$ smèlis $(2,0-0,05 \mathrm{~mm}), 31,2 \%$ sudaro dulkès $(0,05-0,002 \mathrm{~mm})$, o molio $(<0,002 \mathrm{~mm})$ yra $14,1 \%$. Irrengiant bandymą dirvožemis buvo artimas neutraliam $\left(\mathrm{pH}_{\mathrm{KCl}} 6,9\right)$, vidutinio humusingumo
(2,93 \%), mažo fosforingumo $\left(70,6 \mathrm{mg} \mathrm{kg}^{-1} \mathrm{P}_{2} \mathrm{O}_{5}\right)$, vidutinio kalingumo $\left(114,0 \mathrm{mg} \mathrm{kg}^{-1} \mathrm{~K}_{2} \mathrm{O}\right)$. Mineralinès sieros ariamajame sluoksnyje nustatyta $1,83 \mathrm{mg} \mathrm{kg}^{-1}$, o podirvyje - 0,50 $\mathrm{mg} \mathrm{kg}^{-1}$.

Antrajam bandymui pasirinktas smèlingas lengvo priemolio tipingas paprastasis išplautžemis (Orthi-Haplic Luvisols), atvežtas iš Varènos r., LAMMC filialo, Perlojos bandymų stoties lauko. Ariamajame dirvožemio sluoksnyje vyrauja 62,6-63,5 \% smèlis (2,0-0,05 mm), 29,8-30,2\% sudaro dulkès $(0,05-$ $0,002 \mathrm{~mm})$, o molio $(<0,002 \mathrm{~mm})$ yra $6,7-7,2 \%$. Iki bandymo dirvožemis buvo artimas neutraliam $\left(\mathrm{pH}_{\mathrm{KCl}} 6,7\right)$, mažo humusingumo (1,71\%), labai didelio fosforingumo $\left(268,3 \mathrm{mg} \mathrm{kg}^{-1} \mathrm{P}_{2} \mathrm{O}_{5}\right)$, vidutinio kalingumo $\left(135,3 \mathrm{mg} \mathrm{kg}^{-1} \mathrm{~K}_{2} \mathrm{O}\right)$, mineralinès sieros $0-30 \mathrm{~cm}$ dirvožemio sluoksnyje nustatyta $0,50 \mathrm{mg} \mathrm{kg}$, $30-60 \mathrm{~cm}-0,50 \mathrm{mg} \mathrm{kg}$. I vegetacinius indus sudeti poarmeninis ir armeninis dirvožemio sluoksniai (iki $60 \mathrm{~cm}$ ).

\section{Tyrimo schema ir tręšimas}

Bandymuose tirti šie tręšimo siera variantai:

1) $S_{0}$ (siera netręšta);

2) $S_{20}(0,14 \mathrm{~g} S$ indui);

3) $S_{40}(0,28 \mathrm{~g} S$ indui);

4) $S_{60}(0,42 \mathrm{~g} S$ indui $)$

Sieros ir foniniam tręšimui azoto, fosforo ir kalio $\left(\mathrm{N}_{100} \mathrm{P}_{60} \mathrm{~K}_{130}\right)$ trąšos įterptos prieš sèją. Vasariniai kviečiai penkių lapelių tarpsniu papildomai tręšti $\mathrm{N}_{50}$ trąšų norma. Tuo būdu ị kiekvieną indą įterpta po 1,05 $\mathrm{g}(\mathrm{N}), 0,42 \mathrm{~g}\left(\mathrm{P}_{2} \mathrm{O}_{5}\right), 0,91 \mathrm{~g}\left(\mathrm{~K}_{2} \mathrm{O}\right)$. Bandyme naudotas: amonio sulfatas, amonio salietra, amofosas, kalio chloridas. Visų trąšų norma paskaičiuota pagal vegetacinio indo paviršiaus plotą. Trąšos buvo ištirpintos vandenyje ir išlaistytos. Vegetaciniai indai išdèstyti rendomizuotai.

\section{Augalu auginimo agrotechnika}

Tręšimo bandymuose naudoti cilindro formos indai, kurių skersmuo $30 \mathrm{~cm}$, aukštis $-60 \mathrm{~cm}$, ̣̇ juos buvo supilta po 421 dirvožemio. Bandymai daryti keturiais pakartojimais.Vegetaciniai indai išdèstyti visiškai rendomizuotai vegetacinejje aikštelejje, lauke ant padèklų. I kiekvieną indą pasèta po 45 vasarinių kviečių 'Triso' sèklas, sudygus paliktos 35 sèklos. Kiekvienais metais vasariniai kviečiai sèti gegužès mèn. 3-5 d. Derlius išrautas rankomis: 2010 m. - rugpjūčio 3 d., 2011 m. - rugpjūčio 9 d., o 2012 m. - rugpjūčio 10 d. Augalų vegetacijos metu trūkstant drègmès augalai laistyti rankiniu 
būdu atsižvelgiant ị meteorologines sąlygas (sudarant augalų augimui optimalią drègmę). Naudotos šios augalų apsaugos priemonès: insekticidai Karate Zeon 5 SC, Proteus 110 OD ir fungicidas Folikuras 250. Vasarinių kviečių grūdų derlius ịvertintas $14 \%$ drègmés absoliučiai švaria grūdų mase.

\section{Laboratoriniai metodai}

Dirvožemio tyrimai atlikti LAMMC Agrocheminių tyrimų laboratorijoje. Nustatyta: $\mathrm{pH}_{\mathrm{KCl}}-1 \mathrm{~N} \mathrm{KCl}$ ištraukoje potenciometriniu metodu; judrusis fosforas, kalis, kalcis, magnis - Egner-Riehm-Domingo metodu (A-L); humusas - perskaičiuotas iš organinès anglies, kuri nustatyta sauso deginimo būdu analizatoriumi Diuma metodu. LAMMC Žemdirbystès instituto Cheminių tyrimų laboratorijoje kviečiu grūduose nustatytas žalių baltymų kiekis - artimos srities infraraudonųjų spindulių spektrometru NIRS6500, krakmolo - poliarimetru ADP 410, šlapiojo ir sausojo glitimo kiekis - Glutomatic sistema.

Atlikta tyrimų duomenų dispersinè vieno veiksnio analizè (ANOVA versija 4,0 - 2003 m.). Duomenys analizuoti, kai faktinis Fišerio kriterijus $\left(\mathrm{F}_{\text {fakt }}\right)$ buvo didesnis už teorinị. Skirtumai tarp tręšimo variantų ịvertinti mažiausia esminio skirtumo riba $\left(\mathrm{R}_{05}\right)$, skaičiuotas tyrimų metų paklaidų vidurkis (Tarakanovas, 2003). Darbe naudoti simboliai:

* ir ** žymëjimai reiškia: statistiškai patikima esant atitinkamai 95 ir $99 \%$ tikimybès lygiui; $\mathrm{R}_{05}$ - esminio skirtumo riba esant $95 \%$ tikimybès lygiui.

\section{Meteorologinès sąlygos}

2010 m. vasarinių kviečių vegetacijos metu temperatūrų $\left(\geq 10{ }^{\circ} \mathrm{C}\right)$ suma sudare $1775,5^{\circ} \mathrm{C}$, iškrito $354 \mathrm{~mm}$ kritulių, hidroterminis koeficientas buvo 1,99. Gegužès mèn. buvo lietingas, ypač antrają dekadą iškrito daug kritulių ir dèl suplūkto dirvožemio paviršiaus augalai sunkiai ir netolygiai dygo (1 ir 2 pav.). Birželio pirmają dekadą praejjusios liūtys ir vèliau susidariusios palankios sąlygos miltligei plisti turèjo ịtakos tų metų grūdų derliui. Liepos mèn. oro temperatūra atskirose dekadose buvo net $3,3-6,9{ }^{\circ} \mathrm{C}$ aukštesnè už daugiametę vidutinę oro temperatūrą, tai irgi galejo lemti trumpesnę augalu vegetaciją ir mažesni grūdų derlių nei kitais tyrimų metais.

2011 m. vasarinių kviečių vegetacijos metu aktyviưjų temperatūrų $\left(\geq 10^{\circ} \mathrm{C}\right)$ suma sudare $1690,5^{\circ} \mathrm{C}$, iškrito $314 \mathrm{~mm}$ kritulių, hidroterminis koeficientas $-1,86.2011 \mathrm{~m}$. oro temperatūra augalų dygimo ir pirmaisiais augimo tarpsniais buvo artima daugiametei ir palanki augalų augimui. Karšti ir sausi orai vyravo birželio pirmąji dešimtadienį, kai vidutinè paros oro temperatūra buvo net $5,9^{\circ} \mathrm{C}$ aukštesnè už daugiametę. Augalai buvo laistomi ir didesnès žalos dèl sausros nepatyrè. Antroje birželio pusèje ir liepos mèn. orai kviečių augimui buvo palankūs.

$2012 \mathrm{~m}$. kviečių vegetacijos metu aktyviųjų temperatūrų $\left(\geq 10{ }^{\circ} \mathrm{C}\right)$ suma sudare $1592,4{ }^{\circ} \mathrm{C}$, iškrito $303 \mathrm{~mm}$ kritulių. Metai vertinant pagal hidroterminį koeficientą $(1,9)$ buvo drègni. Gausiausiai kritulių iškrito birželio antrajji ir liepos pirmąji dešimtadieniais. 2012 m. vasariniai kviečiai sudygo gerai, tačiau vèliau jiems trūko šilumos, ypač birželio pirmąją dekadą, kai oro temperatūra

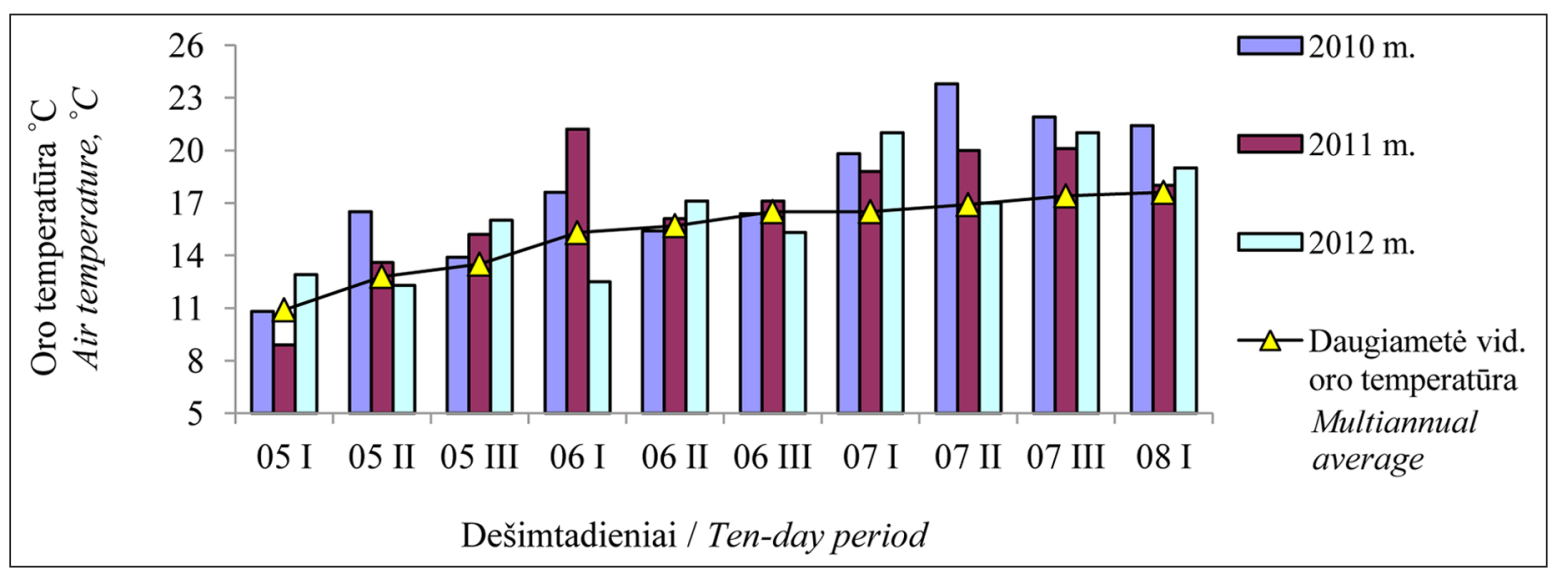

1 pav. Vidutinè paros oro temperatūra $\left({ }^{\circ} \mathrm{C}\right)$ bandymo laikotarpiu

Fig. 1. The average temperature $\left({ }^{\circ} \mathrm{C}\right)$ during the experimental period 


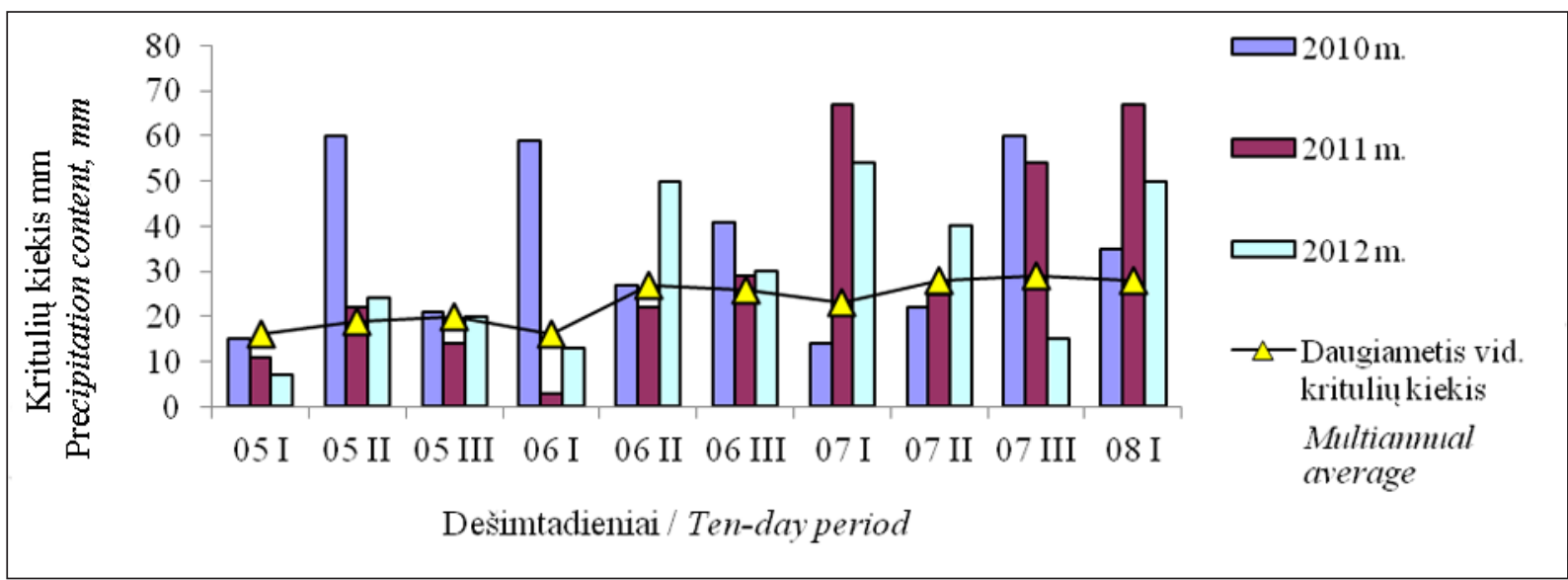

2 pav. Vidutinis kritulių kiekis $(\mathrm{mm})$ bandymo laikotarpiu

Fig. 2 . The average of precipitation $(\mathrm{mm})$ during the experimental period

buvo žemesnè už gegužès mèn. vidutinę paros oro temperatūrą.

\section{TYRIMŲ REZULTATAI IR JŲ APTARIMAS}

\section{Vasarinių kviečių derlius}

Analizuojant tyrimų duomenis matyti, kad 2010 m. buvo mažiau palankūs vasarinių kviečių augimui. Gausios liūtys pristabdè kviečių derliaus formavimosi procesus, ir derlius gautas daug mažesnis, negu kitais dvejais tyrimų metais. Nepaisant to, abiejuose vykdytuose bandymuose sieros trąšos turèjo esminès įtakos grūdų derliui (1 lentelè).

Pirmajame bandyme, kuris atliktas karbonatingame rudžemyje, 2010-2011 m. gautas esmingai didesnis kviečių grūdų derlius, palyginti su kontrole, tręšiant didžiausia sieros trąšų norma $\left(\mathrm{S}_{60}\right) .2010 \mathrm{~m}$. gautas $13,6 \%$ derliaus priedas, o 2011 m. - 43,3 \%. Antraisiais tyrimų metais, palyginti su kontrole, esminis $(\mathrm{P}<0,001)$ derliaus padidejimas nustatytas visuose tręšimo siera variantuose, o patręšus $S_{60}$ gautas iš esmès didesnis derlius visais tyrimų metais. Paskutiniaisiais tyrimų metais gauti kiek kitokie tyrimų duomenys. Didžiausias ir esminis derliaus skirtumas, palyginti su netręštais augalais, gautas, kai augalai tręšti $S_{20}$ trąšų norma. Vidutiniais tyrimų duomenimis, tręšimas siera $\left(\mathrm{S}_{20}-\mathrm{S}_{60}\right)$ karbonatingame rudžemyje esmingai didino vasarinių kviečių derlių, o didžiausias derlius $50,8 \mathrm{~g}$ /inde nustatytas tręšiant $S_{60}$. Kitų mokslininkų teigimu, tręšiant $S_{15}$ trąšų norma kviečių grūdų derlius

1 lentelè. Sieros trąšų normų įtaka vasarinių kviečių derliui g/inde

Ta ble 1. Influence of different rate (S) fertilizers on the spring wheat yield, g/pot

\begin{tabular}{|c|c|c|c|c|c|c|c|c|}
\hline \multirow{3}{*}{$\begin{array}{l}\text { Trąšų } \\
\text { norma } \\
\text { Fertilizer } \\
\text { rate }\end{array}$} & \multicolumn{8}{|c|}{ Dirvožemis / Soil } \\
\hline & \multicolumn{4}{|c|}{$\begin{array}{c}\text { Karbonatingas rudžemis } \\
\text { Calcaric Cambisols }\end{array}$} & \multicolumn{4}{|c|}{$\begin{array}{c}\text { Paprastasis išplautžemis } \\
\text { Haplic Luvisols }\end{array}$} \\
\hline & $2010 \mathrm{~m}$. & $2011 \mathrm{~m}$. & $2012 \mathrm{~m}$. & $\begin{array}{l}\text { Vidurkis } \\
\text { Average }\end{array}$ & $2010 \mathrm{~m}$ & $2011 \mathrm{~m}$. & $2012 \mathrm{~m}$ & $\begin{array}{l}\text { Vidurkis } \\
\text { Average }\end{array}$ \\
\hline $\mathrm{S}_{0}$ & 34,4 & 42,6 & 46,8 & 41,3 & 39,8 & 58,9 & 40,1 & 46,3 \\
\hline $\mathrm{S}_{20}$ & 37,2 & $59,5^{\star *}$ & $52,8^{*}$ & $49,9^{* *}$ & 40,7 & 60,6 & $44,3^{* *}$ & $48,5^{\star *}$ \\
\hline $\mathrm{S}_{40}$ & 37,5 & $54,5^{\star *}$ & 49,7 & $47,2^{\star *}$ & 40,6 & 59,7 & $44,3^{\star *}$ & $48,2^{\star *}$ \\
\hline$S_{60}$ & $39,1^{\star}$ & $61,1^{\star *}$ & $52,3^{\star}$ & $50,8^{\star *}$ & $42,1^{\star}$ & $62,1^{\star *}$ & $49,2^{\star *}$ & $51,1^{\star *}$ \\
\hline $\mathrm{R}_{05}$ & 3,43 & 2,77 & 4,19 & 3,05 & 2,08 & 1,72 & 2,13 & 1,43 \\
\hline $\mathrm{R}_{01}$ & 4,93 & 4,00 & 6,00 & 4,09 & 2,99 & 2,47 & 3,06 & 1,92 \\
\hline
\end{tabular}

Pastaba: ${ }^{*}$ ir ${ }^{\star *}$ - skirtumai esminiai esant atitinkamai 95 ir $99 \%$ tikimybès lygiui.

Note: ${ }^{*}$ and ${ }^{* *}$ - significantly different $(P<0.005)$ and $(P<0.001)$. 
didejo nuo 4,703 iki 5,328 $\mathrm{kg} \mathrm{ha}^{-1}$ (Reussi Calvo, Echeveria, Saiz Rozas, 2006).

Antrajame bandyme, kuris vykdytas paprastajame išplautžemyje, $2010 \mathrm{~m}$. vidutinis kviečių grūdų derlius buvo mažiausias, palyginti su kitais tyrimų metais. Tarp atskirų variantų svyravo nuo $39,8 \mathrm{iki}$ 42,1 g/inde. Esmingai didžiausias derlingumas pasiektas tręšiant $S_{60}$ trąšų norma. Palankesniais vasarinių kviečių augimui $2011 \mathrm{~m}$. vidutinis derlius bandyme gautas didesnis nei $2010 \mathrm{~m}$. Iš esmès didesnis derlius užaugintas taip pat tręšiant $\mathrm{S}_{60}$ trąšų norma, o derliaus priedas siekè 5,4\%. Paskutiniais tyrimų metais labiausiai išryškejo derliaus skirtumai tarp tręšimo siera variantų - 40,1-49,2 g/inde. Visos trąšų normos iš esmès didino vasarinių kviečių derlių, palyginti su augalais, kurie nebuvo tręšti sieros trąšomis, o didžiausią teigiamą itaką grūdų derliui turejo tręšimas $S_{60}$ trąšų norma, derliaus priedas buvo net $22,7 \%$. Vidutiniais tyrimų duomenimis, tręšimas siera iš esmès didino vasarinių kviečių derlių ir didžiausias grūdų derlius užaugintas tręšiant $S_{60}(51,1 \mathrm{~g} /$ inde). Tręšimas siera didino derlių, palyginti ne tik su netręštu (kontroliniu) variantu, bet ir su tręštais $S_{20}$ ir $S_{40}$ normomis variantais. S. P. McGrath, F. J. Zhao, M. M. A. Blake-Kalff (2002) teigimu, sieros $10-20 \mathrm{~kg} \mathrm{ha}^{-1}$ norma bandymuose derlių didino $12-16 \%$.
Apibendrinant duomenis matyti, kad didesnis sieros trąšų efektyvumas grūdų derliui yra vasarinius kviečius auginant karbonatingajame rudžemyje.

\section{Žalių baltymų kiekis}

Žalių baltymų kiekis kviečiu grūduose yra vienas iš pagrindinių jų kokybès kriterijų, gali kisti nuo 6 iki 20 \% (SM). Sieros trūkumas reikšmingai veikè kviečių derlių ir kokybę (Zhao, Hawkesford, McGrath, 1999a; Györi, 2005). Siera turi ittakos ne tik grūdų, bet taip pat vaidina svarbų vaidmeni ir kepinių kokybei. Geros kokybès duonai iškepti yra naudojami miltai, malami iš 11 ir daugiau \% baltymų (SM) turinčiu grūdų (Atwell, 2001). Tręšimas siera dažnai nelemia tiesiogiai žalių baltymų kiekio, bet turi tendenciją didinti baltymų gelio svorị miltuose, tešla tampa tąsesnè. Mokslininkas B. R. Singh (2003) atskleidè stipria koreliaciją tarp duonos kepalo tūrio ir sieros kiekio grūduose. Kai kurie tyrimai rodo, kad kepimo savybès labiau koreliuoja su sieros koncentracija grūduose, negu su azoto (Zhao, Salmon, Withers, Monaghan, Evans, Shewry, Mc Grath, 1999b).

2010 m. saulèti ir šilti orai kviečių žydejjimo ir užmezgimo laikotarpiu lèmé didesnị vidutinị grūdų baltymingumą (16,2\%), palyginti su kitais tyrimų

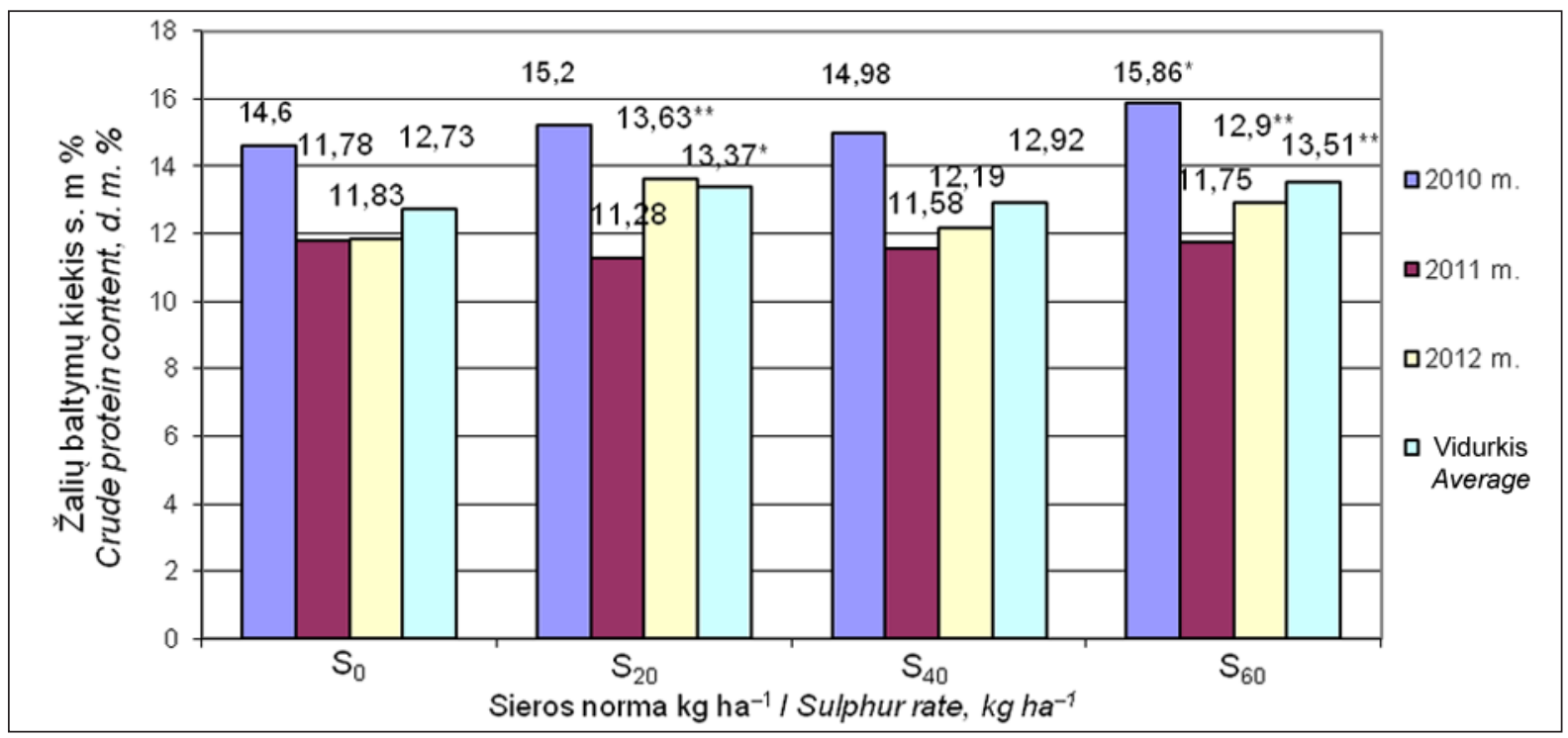

3 pav. Sieros trąšų normų ịtaka žalių baltymų kiekiui vasarinių kviečių grūduose karbonatingame rudžemyje Fig. 3. Influence of sulphur fertilizer rate on the protein content in spring wheat grown in Epicalcari - Endohypogleyic Cambisol

Pastaba: ${ }^{* *}$ - skirtumai esminiai esant atitinkamai $99 \%$ tikimybès lygiui.

Note: ${ }^{*}$ - significantly different $(P<0.001)$. 
metais (3 pav.). Sieros trąšų ịtaka baltymų kiekiui išryškejjo vasarinius kviečius auginant karbonatingame rudžemyje - baltymų padaugèjo $1,3 \%$ vnt. tręšiant $S_{20}$ trąšų norma, o padidinus trąšų normas iki $S_{40}$ ar $S_{60}$, pastebèta baltymų mažejimo tendencija.

$2011 \mathrm{~m}$. baltymų kiekis grūduose tręšiant $S_{20}$ trąšų norma didejo 7,5 \% vnt., palyginti su netręštais augalais, tačiau šis padidejimas nebuvo esminis. Toliau didinant tręšimo normas stebèta baltymų mažejimo tendencija.

2012 m., kurie meteorologinèmis sąlygomis buvo panašūs ì 2011 m., vidutinis grūdų baltymingumas sieke 13,9\%. Tretieji tyrimų metai patvirtino tas pačias tendencijas, kaip ir ankstesni dveji metai, kad $S_{20}$ trąšų norma tręštuose kviečių grūduose susikaupia didesnis kiekis baltymų, palyginti su netręštais augalais. Toliau didinant trąšų normas stebime mažejjantị baltymų kiekį. Argentinos mokslininkų atliktų tyrimų duomenimis, sieros trąšos neturejo įtakos žalių baltymų kiekiui (Reussi Calvo, Echeveria, Saiz Rozas, 2006).

Apibendrinant trejų metų duomenis matome, jog sieros trąšos karbonatingame rudžemyje auginamiems kviečiams yra efektyvesnès nepalankiais baltymų kaupimuisi grūduose metais.

Antrajame bandyme (paprastajame išplautžemyje), kaip ir pirmajame, palankiausi baltymų susikaupimui buvo $2010 \mathrm{~m}$. (4 pav.). Vidutinis grūdu baltymingumas sieke 15,2 \%, o $2011 \mathrm{~m}$. ir 2012 m., atitinkamai - 11,6 \% ir 12,6 \%. 2010 m. grūdų baltymingumas iš esmès didèjo tręšiant $S_{60}$ trąšų norma, palyginti su kviečiais, kurie nebuvo tręšti siera. Antraisiais tyrimų metais didžiausias grūdų baltymingumas buvo tuomet, kai sieros trąšos nebuvo naudojamos, o sieros normų didinimas sąlygojo mažesni grūdų baltymingumą. Panašius rezultatus gavo ir mokslininkai, atlikę bandymus Žemdirbystès institute (Šiaudinis, 2007). 2012 m. esminès ịtakos baltymų kiekiui turèjo tręšimas $S_{20}$ trąšų norma. Grūdų baltymingumas didejo 15,2 \% vnt., palyginti su netręštais kviečiais.

Kviečiai yra krakmolingi, grūduose krakmolas sudaro 63-72 \% (SM). Krakmolo kiekis grūduose nustatytas 2010 ir $2012 \mathrm{~m}$. Visais tyrimų metais abiejuose bandymuose tręšiant sieros trąšomis krakmolo kiekis mažèjo. Karbonatingame rudžemyje užaugintų kviečių grūdų krakmolo kiekis kito 63,45-63,85 \% (SM). Didžiausias krakmolo kiekis nustatytas, kai augalai nebuvo tręšti siera. Grūdų brendimo laikotarpiu vyravo aukšta temperatūra, todèl sulètèjo krakmolo sintezè, ir krakmolo kiekis grūduose buvo mažesnis nei $2012 \mathrm{~m}$. Paskutiniais metais vidutinis krakmolo kiekis, nustatytas bandyme siekè 66,6 \% (SM) ir kito 65,8-67,6 \% (SM) ribose.

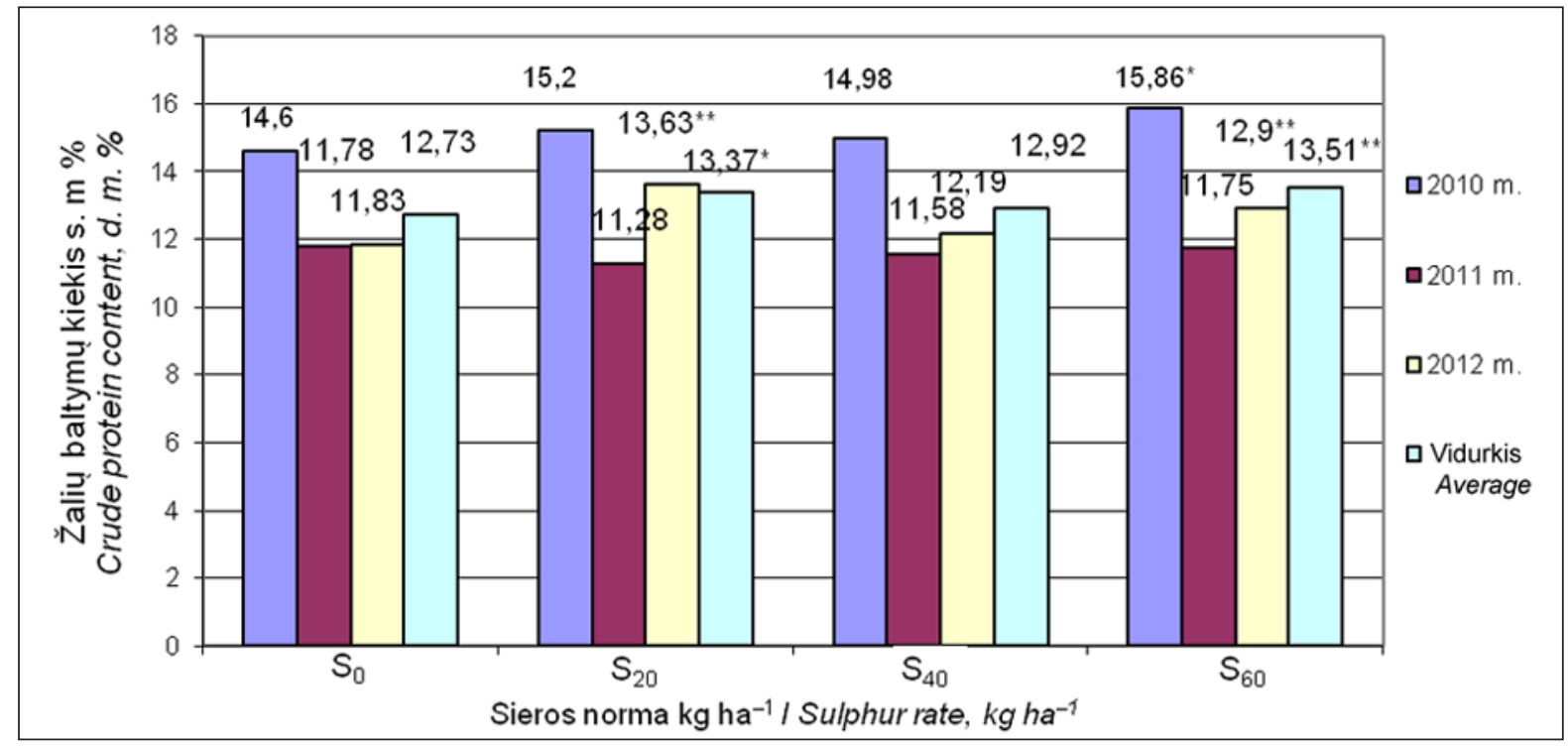

4 pav. Sieros trąšų normų įtaka žalių baltymų kiekiui vasarinių kviečių grūduose paprastajame išplautžemyje Fig. 4. Influence of sulphur fertilizer rate on the protein content in spring wheat grown in Haplic Luvisol Pastaba: ${ }^{*}$ ir ${ }^{* *}$ - skirtumai esminiai esant atitinkamai 95 ir $99 \%$ tikimybès lygiui. Note: ${ }^{*}$ and ${ }^{* *}$ - significantly different $(P<0.005)$ and $(P<0.001)$. 


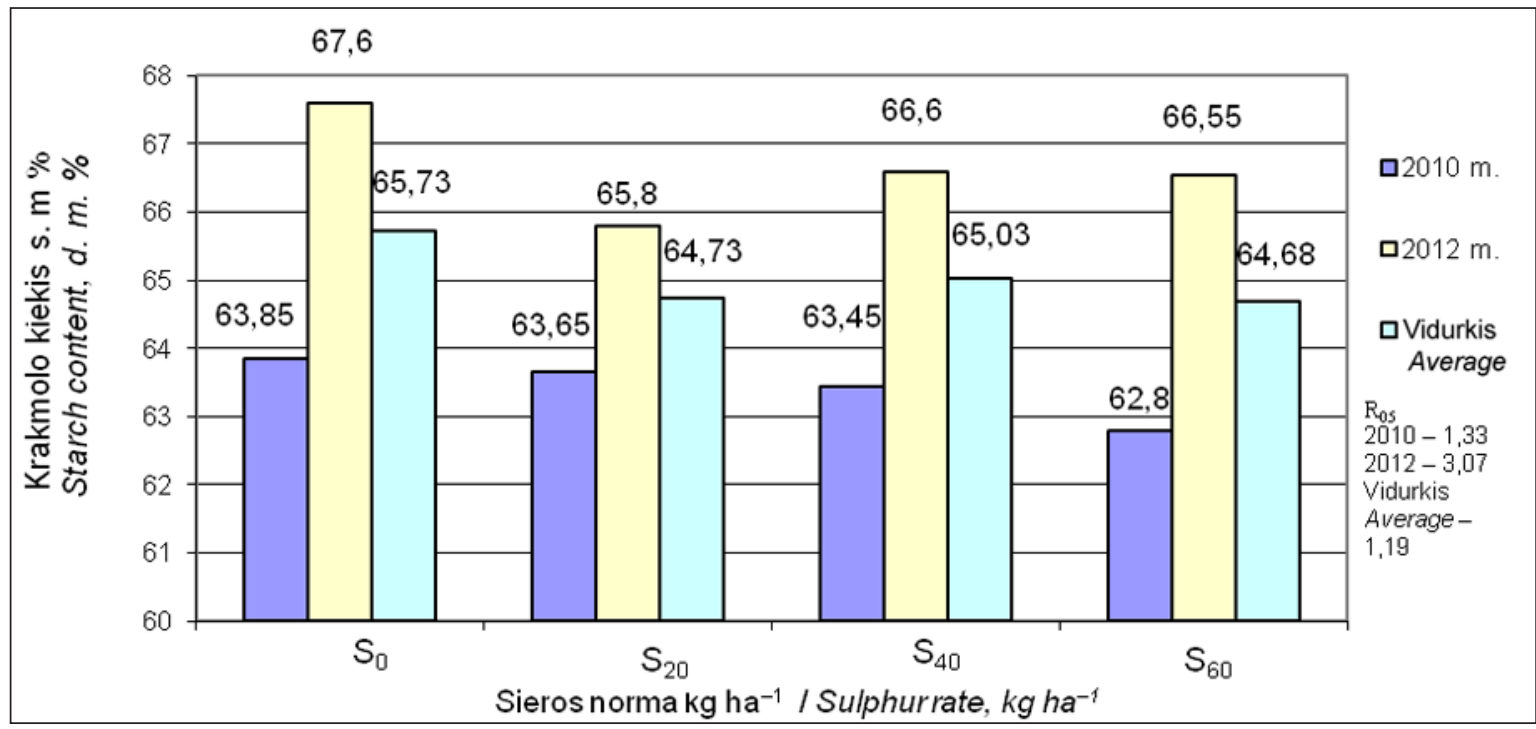

5 pav. Sieros trąšų normų įtaka krakmolo kiekiui vasarinių kviečiu sèklose karbonatingame rudžemyje Fig. 5. Influence of sulphur fertilizer rate on the starch content in spring wheat grown in Epicalcari - Endohypogleyic Cambisol

Paprastajame išplautžemyje $2010 \mathrm{~m}$. bandyme nustatytas vidutinis krakmolo kiekis - 64,9 \% (SM). Didžiausias jo kiekis susikaupe grūduose, kai kviečiai nebuvo tręšti siera. Naudojant $S_{20}, S_{40}$, $\mathrm{S}_{60}$ trąšų normas krakmolo kiekiai mažejo atitinkamai $0,38,1,37,3,58 \%$ vnt. 2012 m. nustatytas vidutinis krakmolo kiekis buvo 64,9\% (SM), o tręšimas siera turèjo tendenciją mažinti jo kiekị didejant baltymingumui.

Kviečių grūduose pagrindiniai glitimą formuojantys baltymai yra gliuteninai ir gliadinai. Jei grūduose mažai šlapiojo glitimo, vèliau mil- tai mažiau sorbuoja vandens, ir minkoma tešla labiau praskysta (Krejčíŕová, Capouchová, Petr, Bicanová, Kvapil, 2006). Mūsų bandyme 2010 m. buvo palankiausi šlapiojo glitimo susikaupimui, karbonatingame rudžemyje augintų kviečių grūduose jo kiekis iš esmès padidejo tręšiant augalus $\mathrm{S}_{60}$ trąšų norma, atitinkamai 4,4 \% vnt. (2 lentelè). Antraisiais tyrimų metais grūduose šlapiojo glitimo susikaupe $14,36 \%$ mažiau, nei pirmaisiais. Sieros trąšų normos, padidintos iki $\mathrm{S}_{40}$, didino ir šlapiojo glitimo kiekị, tačiau neesmingai. 2012 m. vidutinis šlapiojo glitimo kiekis buvo

\section{2 le ntelè. Sieros trąšų normų įtaka vasarinių kviečių šlapiojo ir sausojo glitimo kiekiui \% SM karbonatingame} rudžemyje

Table 2. Influence of different rate (S) fertilizers on spring wheat wet and dry gluten, \% DM in Epicalcari - Endohypogleyic Cambisol

\begin{tabular}{|c|c|c|c|c|c|c|c|c|}
\hline \multirow{4}{*}{$\begin{array}{c}\text { Trąšų } \\
\text { norma } \\
\text { Fertilizer } \\
\text { rate }\end{array}$} & \multicolumn{8}{|c|}{ Dirvožemis / Soil } \\
\hline & \multicolumn{8}{|c|}{ Karbonatingas rudžemis / Calcaric Cambisols } \\
\hline & \multicolumn{4}{|c|}{ Šlapiasis glitimas / Wet gluten } & \multicolumn{4}{|c|}{ Sausasis glitimas / Dry gluten } \\
\hline & $2010 \mathrm{~m}$. & $2011 \mathrm{~m}$. & $2012 \mathrm{~m}$. & $\begin{array}{l}\text { Vidurkis } \\
\text { Average }\end{array}$ & $2010 \mathrm{~m}$ & $2011 \mathrm{~m}$ & $2012 \mathrm{~m}$. & $\begin{array}{l}\text { Vidurkis } \\
\text { Average }\end{array}$ \\
\hline $\mathrm{S}_{0}$ & 34,91 & 19,85 & 21,45 & 25,40 & 11,50 & 6,47 & 6,85 & 8,27 \\
\hline $\mathrm{S}_{20}$ & 34,32 & 20,95 & 22,20 & 25,82 & 11,55 & 6,91 & 7,02 & 8,49 \\
\hline $\mathrm{S}_{40}$ & 34,60 & 21,10 & 23,50 & 26,40 & 11,45 & 6,92 & 7,50 & 8,62 \\
\hline$S_{60}$ & $36,45^{\star}$ & 20,93 & 21,22 & 26,20 & 11,95 & 6,87 & 6,56 & 8,46 \\
\hline $\mathrm{R}_{05}$ & 1,42 & 3,66 & 4,58 & 3,48 & 0,96 & 1,09 & 1,61 & 1,25 \\
\hline
\end{tabular}

Pastaba: ${ }^{\star}$ - skirtumai esminiai esant atitinkamai $95 \%$ tikimybès lygiui.

Note: ${ }^{*}$ - significantly different $(P<0.005)$. 


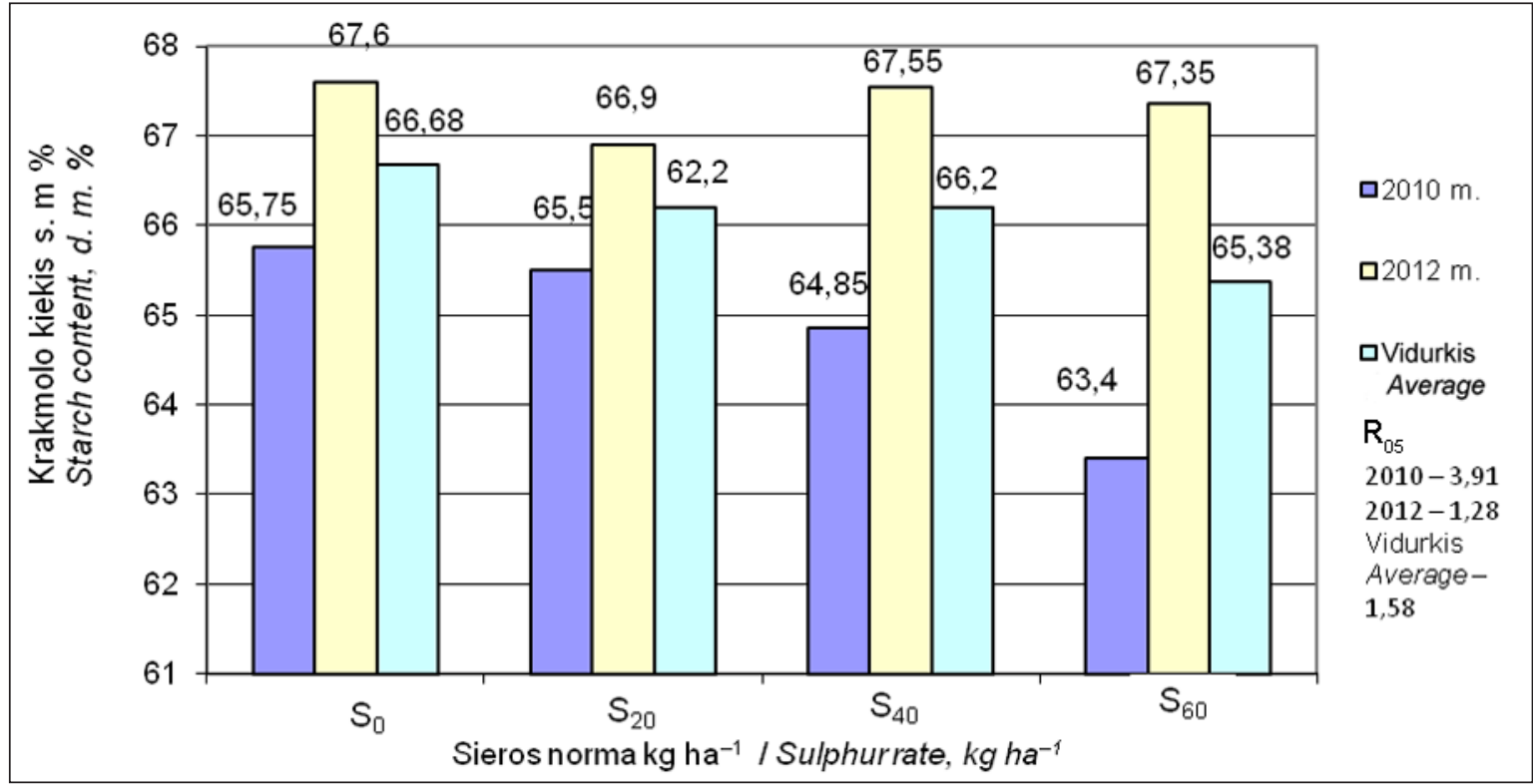

6 pav. Sieros trąšų normų ịtaka krakmolo kiekiui vasarinių kviečių sẻklose paprastajame išplautžemyje Fig. 6. Influence of sulphur fertilizer rate on the starch content in spring wheat grown in Haplic Luvisol

šiek tiek didesnis, o sieros trąšų normų didinimas iki $\mathrm{S}_{40}$, kaip ir 2011 m., didino jo kiekí, tačiau neesmingai.

Didžiausias sausojo glitimo kiekis nustatytas 2010 m. (vidutiniškai bandyme - 11,61 \% SM). Esminio sieros trąšų poveikio šiam kokybès rodikliui tais metais nenustatyta. 2011 ir $2012 \mathrm{~m}$. sausojo glitimo kiekis vidutiniškai buvo 6,79 ir 6,98 \% SM, o didinant sieros trąšų normą iki $\mathrm{S}_{40}$ nustatytos sausojo glitimo kiekio didejimo tendencijos.

Paprastajame išplautžemyje auginti vasariniai kviečiai (kaip ir karbonatingame rudžemyje) dau- giau sausojo ir šlapiojo glitimo sukaupè $2010 \mathrm{~m}$., atitinkamai 10,9 ir 33,1 \% SM (3 lentelè). Pirmaisiais tyrimų metais paprastajame išplautžemyje tręšiant $S_{60}$ trąšų norma iš esmès didejo šlapiojo glitimo kiekis (7,9 \% vnt.), taip pat vidutiniais trejų tyrimų metų duomenimis, tręšiant $S_{60}$ trąšų norma nustatyta stipriausia šlapiojo ir sausojo glitimo kiekio didejjimo tendencija.

Tręšiant $S_{20}$ trąšų norma nustatytas esminis sausojo glitimo sumažejimas (13,9 \% vnt.), o $2012 \mathrm{~m}$. ta pati sieros trąšų norma iš esmès didino $(23,4 \%$ vnt.) sausojo glitimo kieki.

3 lentelè. Sieros trąšų normų įtaka vasarinių kviečių šlapiojo ir sausojo glitimo kiekiui \% SM paprastajame išplautžemyje

Table 3. Influence of different rate (S) fertilizers on spring wheat wet and dry gluten, \% DM in Haplic Luvisol

\begin{tabular}{|c|c|c|c|c|c|c|c|c|}
\hline \multirow{4}{*}{$\begin{array}{l}\text { Tręšų } \\
\text { norma } \\
\text { Fertilizer } \\
\text { rate }\end{array}$} & \multicolumn{8}{|c|}{ Dirvožemis / Soil } \\
\hline & \multicolumn{8}{|c|}{ Paprastasis išplautžemis / Haplic Luvisols } \\
\hline & \multicolumn{4}{|c|}{ Šlapiasis glitimas / Wet gluten } & \multicolumn{4}{|c|}{ Sausasis glitimas / Dry gluten } \\
\hline & $2010 \mathrm{~m}$. & $2011 \mathrm{~m}$. & $2012 \mathrm{~m}$. & $\begin{array}{l}\text { Vidurkis } \\
\text { Average }\end{array}$ & $2010 \mathrm{~m}$. & $2011 \mathrm{~m}$. & $2012 \mathrm{~m}$. & $\begin{array}{l}\text { Vidurkis } \\
\text { Average }\end{array}$ \\
\hline $\mathrm{S}_{0}$ & 31,95 & 18,10 & 18,68 & 22,91 & 10,25 & 5,83 & 5,55 & 7,21 \\
\hline $\mathrm{S}_{20}$ & 33,55 & $15,60^{*}$ & 21,25 & 23,47 & 10,85 & $5,02^{\star}$ & $6,85^{\star}$ & 7,57 \\
\hline $\mathrm{S}_{40}$ & 32,43 & 16,50 & 19,25 & 22,72 & 11,35 & 5,25 & 6,13 & 7,58 \\
\hline$S_{60}$ & $34,50^{*}$ & 16,75 & 19,65 & 23,63 & 11,05 & 5,42 & 6,20 & 7,56 \\
\hline $\mathrm{R}_{05}$ & 2,50 & 2,44 & 4,05 & 3,09 & 2,05 & 0,71 & 0,77 & 1,33 \\
\hline
\end{tabular}

Pastaba: ${ }^{*}$ - skirtumai esminiai esant atitinkamai $95 \%$ tikimybès lygiui.

Note: *- significantly different $(P<0.005)$. 


\section{IŠVADOS}

1. Vidutiniais 2010-2012 m. tyrimų duomenimis, karbonatingame rudžemyje ir paprastajame išplautžemyje sieros trąšos turèjo esminès ịtakos vasarinių kviečių grūdų derliaus padidejimui, didžiausias derlius gautas tręšiant $\mathrm{S}_{60}$ trąšų norma. Didesnis sieros trąšų efektyvumas derliui nustatytas vasarinius kviečius auginant karbonatingame rudžemyje.

2. Vidutiniais trejų tyrimų metų duomenimis, nustatyta teigiama sieros trąšų normų įtaka vasarinių kviečiu grūdų baltymingumui. Žalių baltymų kiekis gautas iš esmès didesnis karbonatingame rudžemyje tręšiant $S_{20}$ trąšų norma, o paprastajame išplautžemyje $-S_{20}$ ir $S_{60}$.

3. Vidutiniais duomenimis, abiejuose bandymuose sieros trąšos neturèjo esminès ịtakos krakmolo kiekiui kviečių grūduose. Tręšimas sieros trąšomis turejo tendenciją didinti sausojo glitimo kieki abiejuose bandymuose.

\section{PADE்KA}

Straipsnyje pateikta dalis tyrimų rezultatų, gautų vykdant LAMMC mokslinių tyrimų programą „Žemès ūkio bei miškų dirvožemių našumas ir tvarumas".

Gauta 20130826

Priimta 20131216

\section{LITERATŪRA}

1. Adomaitis T., Mažvila J., Vaišvila Z., Arbačiauskas J., Antanaitis A., Lubytė J., Šumskis D. 2010. Ilgalaikio tręšimo įtaka anijonų išsiplovimui. ŽemdirbystéAgriculture. T. 97. Nr. 1. P. 71-82.

2. Atwell W. A. 2001. An overview of wheat development, cultivation, and production. Cereal Food World. Vol. 46. P. 59-62.

3. Castle S. L., Randall P. J. 1987. Effects of sulphur deficiency on the synthesis and accumulation of proteins in the developing wheat seed. Australian Journal of Plant Physiology. Vol. 14. P. 503-516.

4. Flæte N. E. S., Hollung K., Ruud L., Sogn T., Færgestad E. M., Skarpeid H. J., Magnus E. M., Uhlen A. K. 2005. Combined nitrogen and sulphur fertilisation and its effect on wheat quality and protein composition measured by SE-FPLC and proteomics. Journal of Cereal Science. Vol. 41. P. 357-369.

5. Fullington J. G., Miskelly D. M., Wrigley C. W., Kasandra D. D. 1987. Quality-related endosperm proteins in sulphur-deficient and normal wheat grain. Journal of Cereal Science. Vol. 5. P. 233-245.

6. Györi Z. 2005. Sulphur content of winter wheat grain in long term field experiments. Communications in Soil Science and Plant Analysis. Vol. 36. P. 373-382.

7. Guzys S., Aksomaitiene R. 2005. Migration of sulphur in limed soils differing in agricultural management. Nutrient Cycling in Agroecosystems. Vol. 71. P. 191-201.

8. Hocking P. J. 1994. Dry-matter production, mineral nutrient concentration, and nutrient distribution and re-distribution in irrigated spring wheat. Journal of Plant Nutrition. Vol. 17. P. 1289-1308.

9. Krejčířová L., Capouchová I., Petr J., Bicanová E., Kvapil R. 2006. Protein composition and quality of winter wheat from organic and conventional farming. Žemdirbysté-Agriculture. T. 93. Nr. 4. P. 285296.

10. McGrant S. P., Zhao F. J., Blake-Kalff M. M. A. 2002. Sulphur in soils: processes, behaviour and measurement. Proceedings No. 499. York, UK: International Fertiliser Society.

11. Mestelan S., Pazos S. 1998. Diagnóstico de la disponibilidad de S para molisoles del centro de la provincia de Buenos Aires según metodología DRIS y el análisis de la relacíon N/S en grano en cultivo de trigo. IV Congreso Nacionalde Trigo. Mar del Plata, Buenos Aires, 11 al 13 de noviembre de 1998. P. 3-39.

12. Moss H. J., Wrigley C. W., MacRitchie F., Randall P. J. 1981. Sulfur and nitrogen fertilizer effects on wheat. II. Influence on grain quality. Australian Journal of Agricultural Research. Vol. 32. P. 213226.

13. Moss H. J., Randall P. J., Wrigley C. W. 1983. Alteration to grain, flour and dough quality in three wheat types with variation in soil sulphur supply. Journal of Cereal Science. Vol. 1. P. 255-264.

14. Reussi Calvo N. I., Echeveria H. E, Saiz Rozas H. 2006. Wheat response to sulphur fertilization in the southeast of Buenos Aires. Ciencia del Suelo. Vol. 24. No. 1. P. 77-87.

15. Singh B. R. 2003 Sulfur and crop quality - agronomical strategies for crop improvement. Abstracts of COST Action 829 Meetings. Braunschweig, Germany. P. 35-36.

16. Šiaudinis G. 2007. Sieros ir azoto ịtaka vasariniu kviečiu ir vasariniu rapsu derliui ir derliaus formavimosi elementams. Akademija: Lietuvos žemès ūkio universitetas. $85 \mathrm{p}$.

17. Tarakanovas P., Raudonius S. 2003. Agronominiu tyrimu duomenu statistine analizé taikant kompiuterines programas ANOVA, STAT, SPULIT-PLOT iš paketo SELEKCIJA ir IRRISTAT. Akademija: Lietuvos žemès ūkio universitetas. $57 \mathrm{p}$.

18. Wieser A., Guster R., Tucher S. 2004. Influence of sulphur fertilisation on quantities and proportions 
of gluten protein types in wheat flour. Journal of Cereal Science. Vol. 40. P. 239-244.

19. Wrigley C. W., Du Cros D. L., Fullington J. G., Kasarda D. D. 1984. Changes in polypeptide composition and grain quality due to sulfur deficiency in wheat. Journal of Cereal Science. Vol. 2. P. 15-24.

20. Zhao F. J., Hawkesford M. J., McGrath S. P. 1999a. Sulphur assimilation and effects on yield and quality of wheat. Journal of Cereal Science. Vol. 30. Issue 1. P. 1-17.

21. Zhao F. J., Salmon S. E., Withers P. J. A., Monaghan J. M., Evans E. J., Shewry P. R., Mc Grath S. P. 1999 b. Variation in the breadmaking quality and rheological properties of wheat in relation to sulphur in three wheat varieties. Journal of the Science of Food and Agriculture. Vol. 79. P. 18651874.
Rūta Staugaitienè, Alvyra Šlepetienè, Lina Žičkienè

\section{THE EFFECT OF SULPHUR FERTILISATION ON GRAIN YIELD AND QUALITY OF SPRING} WHEAT

Sum mary

Two pot experiments were carried out at the experimental site of the Agrochemical Research Laboratory of the Lithuanian Research Centre for Agriculture and Forestry in 20102012. Two types of soil were used in the experiments: sandy light loamy Epicalcari - Endohypogleyic Cambisol from the Skemiai Experiment Field, Radviliškis Region, and sandy loamy Haplic Luvisol from the Perloja Experiment Field, Varena Region. Spring wheat of 'Triso' variety was grown in the pots. The following sulphur fertilisation scheme was applied: not treated, treated with $\mathrm{S}_{20}, \mathrm{~S}_{40}$ and $\mathrm{S}_{60}$ rates. The data obtained from our experiments suggest that sulphur fertilisation had a positive effect on the grain yield of spring wheat grown on both soil types. The highest yield of spring wheat was obtained when $S_{60}$ rate was applied. Higher efficiency of sulphur fertiliser was obtained when spring wheat was grown on calcaric Cambisol. Significantly higher content of crude protein in grains was obtained when spring wheat, grown on calcaric Cambisol, was treated with $\mathrm{S}_{20}$ rate. The grains of spring wheat grown on Hapli-Albic Luvisol were significantly higher in crude protein when $\mathrm{S}_{20}$ and $\mathrm{S}_{60}$ rates were applied. The data obtained from both experiments suggest that sulphur fertilisation had no significant effect on the starch content in spring wheat grains, yet there were some positive effects on dry gluten content - it tended to increase.

Key words: soil, sulphur, spring wheat, protein, gluten 